\title{
BIOCHEMICAL CONSTITUENTS OF DIFFERENT PARTS OF MULBERRY GENOTYPES
}

\author{
VENKATESH KUMAR R. AND SEEMA CHAUHAN* \\ *Department of Applied Animal Sciences, School of Biosciences and Biotechnology, Babasaheb Bhimrao Ambedkar \\ University (A Central University), Vidya Vihar, Raebareli Road, Lucknow-226025, UP, India \\ *Corresponding Author: Email - seemachauhan.1982@gmail.com
}

Received: June 01, 2011; Accepted: August 08, 2011

\begin{abstract}
Mulberry leaf exclusively assures the growth and development of the silkworm larvae, being considered a complete value nutrient, so that the knowledge of its nutritional status is of great interest. The nutritional status of different mulberry varieties is ascertained by its biochemical constituents. Mulberry is rich sources of protein, carbohydrate, carotenoids, lipids, ascorbic acid, anthocyanins etc. Hence the current investigation was undertaken to study the biochemical constituents in different parts viz, roots, leaves and fruits of seven mulberry genotypes. The results indicated that AR-12 mulberry variety have recorded highest biochemical constituents.
\end{abstract}

Keywords: Mulberry, roots, leaves, fruits and Biochemical constituents

\section{Introduction}

Mulberry (Morus spp.) leaves have been the traditional feed for the silk worm (Bombyx mori). The growth and development of the silkworm larvae and subsequently cocoon production are greatly influenced by nutritional quality of mulberry leaves $[3,27]$. Mulberry leaves are rich source of proteins, carbohydrates, chlorophyll $a$, chlorophyll b, total chlorophyll and total carotenoids, ascorbic acid and various mineral elements. Deficiency of certain nutrients or an imbalance of nutrients in leaves cause changes in the composition or metabolic activity of silkworm larval body [21].

Mulberry has been selected and improved for leaf quality and yield for a long time. The main use of mulberry globally is as feed for the silkworm, but depending on the location, it is also appreciated for its fruit (consumed fresh, in juice or as preserves), as a delicious vegetable (young leaves and stems), for its medicinal properties in infusions (mulberry leaf tea), for landscaping and as animal feed. In Peru, the multiple uses of mulberry have been recognized [46]. There are several places where mulberry is utilized traditionally as a feed in mixed forage diets for ruminants, like in certain areas of India, China and Afghanistan. In Italy there have been several studies on the use of mulberry for dairy cows and other domestic animals $[6,33,42,44]$ and in France there was a research project to introduce mulberry in livestock production [4].

The mulberry fruits are also known for its delicious taste and medicinal properties like vaso-tonic, anti-oxidant activity, anti-cancer, anti-viral, anti-inflammatory etc. [27]. Besides this, they are using for both medical and cosmetic purposes like to nourish skin and blood, benefit to liver, kidney and treat weakness. Botanically, the mulberry fruits are not a true berry, it is an aggregate fruit composed of smaller fruits called drupes, appearing like a swollen loganberry and highly sweet, succulent. Mulberry fruits are rich in glucose, sucrose, carotenes, vitamin B1, vitamin B2, vitamin C, tartaric acid and anthocyanins etc. The fruits contain high quantity of carbohydrate, anthocyanins and exploited for rich source of natural red food colorant proteins. The safety of synthetic pigments has been questioned, leading to reduction of number of permitted colorants [17]. Due to this limitation worldwide consumption tendency towards use of natural products as natural colorants has been increased significantly [37]. Besides their color attributes, anthocyanins have been reported to be beneficial to health as potent anti-oxidants and to improve visual acuity [34]. The major anthocyanins identified in fruit extract are cyanidin 3-glucoside and cyaniding 3rutinoside $[32,41]$. Many medicinal properties have been proved by clinical studies on various compounds present in mulberry (flavanoids, alkaloids, steroids) are responsible for therapeutic benefits [5]. The root bark of mulberry tree in the first Chinese dispensatory "Shen Nong Ben Cao Jing" whose original anonymous volume probably appeared by the end of the third century. In the book, the root bark of the plant is called as 'Sang Bai Pi' $[35,36]$. The herb has been used as anti-phlogistic, diuretic, expectorant and anti-diabetic in traditional Chinese medicine $[8,36]$. A piperidine alkaloid (moranoline = 1-deoxynojirimycin) and glycoproteins (morans $A$ and $20 \mathrm{~K}$ ) were isolated as anti-diabetic agents from Morus root bark and leaves [18, 24, 45]. On the other hand, the antioxidant potency of some phenolic compounds (flavonoids, stilbenes and 2arylbenzofurans) from Morus alba has been reported [14, $15,22,39]$. 
The consumption of such biochemical constituents of this mulberry plant serves as dietary disease preventive food components. However, fewer efforts have been made to evaluate the biochemical constituents available in different parts of mulberry. Therefore, the present investigation was conducted to evaluate biochemical composition on different parts i.e. leaves, fruits and roots of mulberry genotypes found in India.

\section{Materials and methods Plant Materials}

Mulberry leaves were collected from the experimental garden of Babasaheb Bhimrao Ambedkar Central University, Lucknow, Uttar Pradesh, India. Seven different mulberry varieties namely S-13, S-146, S-1, AR12, S-36, S-54, and BR-2 were selected for the present investigation. 10 grams of different parts of mulberry samples were selected for estimation for their biochemical compositions such as protein, carbohydrate, total carotenoids, and total lipids contents in roots, leaves and fruits. Three replications were maintained for each variety throughout the experiment.

\section{Determination of protein}

Protein content was quantitatively measured by Lowry's method [30]. About $5 \mathrm{gm}$ of different parts of mulberry samples viz, roots, leaves and fruits of different gentotypes was crushed and grinded in $50 \mathrm{ml}$ of Trichloroacetic acid solution. The grinded material was collected and centrifuged at 4000 r.p.m. for 15 minutes. The clear supernatants were collected in different test tubes for assay for protein content by addition of Folin's reagent. The elucidation turns blue in colour. The absorbance of blue colour was measured with the help of U.V. Spectrophotometer at $650 \mathrm{~nm}$ wavelength. The protein content was calculated by standard Boven Serum Albumin. The results were expressed in $\mathrm{mg} / \mathrm{gm}$.

\section{Determination of carbohydrate}

Carbohydrates content in different mulberry samples was quantitatively measured by Dubois et al [9]. For estimation of carbohydrates content, $2 \mathrm{~g}$ leaves of different parts of mulberry samples viz, roots, leaves and fruits were grinded in distilled water with the help of mortar and pestle. Then leaf samples were centrifuged at $5000 \mathrm{rpm}$ for 10 minutes. $0.5 \mathrm{ml}$ clear supernatants with $0.5 \mathrm{ml}$ distilled water were collected in different test tubes and $4 \mathrm{ml}$ of Anthrone reagent was added to obtain green colour. The absorbance of green colour was taken to estimate the carbohydrate content at $625 \mathrm{~nm}$ wavelength by using U-V Spectrophotometer. The carbohydrates content was calculated by standard sugar solutions (Dextrose L) method and is measured in $\mathrm{mg} / \mathrm{gm}$.

\section{Determination of Total Carotenoids}

Total carotenoid was quantitatively measured by Ranganna method [38]. About $0.20 \mathrm{gm}$ of different parts of mulberry samples viz, roots, leaves and fruits was grinded and extracted in $80 \%$ acetone solution till the colour of sample became colourless. The clear supernatants were taken to determine the absorbance at two wavelengths 480 and $510 \mathrm{~nm}$, respectively against $80 \%$ acetone as blank. The absorbance of fruit samples was taken at different wavelengths and calculated the amount of total carotenoids in $\mathrm{mg} / \mathrm{gm}$ tissue.

\section{Determination of Total anthocyanin content}

About 2 gms of mulberry fruits of different genotypes were weighed and blended with same amount of ethanolic - $\mathrm{HCl}$. The samples were left for $24 \mathrm{hrs}$. for maximum extraction of anthocyanins at $4^{\circ} \mathrm{C}$. After 24 hours, the extracted material was filtered through Whatman filter paper and made to a known volume with ethanolic- $\mathrm{HCl}$. Absorbance was determined at $535 \mathrm{~nm}$ against ethanolic - $\mathrm{HCl}$ as blank with the help of U.V. Spectrophotometer and calculated the total anthocyanin content with the help of following formula [38].

$$
\begin{aligned}
& \begin{array}{lll}
\text { Absorbance at } & \text { volume made } & \\
535 \mathrm{~nm} & \mathrm{X} \text { up of extract } \mathrm{X} \text { Total volume X } 100
\end{array} \\
& \text { used for colour } \\
& \text { Total O.D. } \operatorname{per} 2 g=\quad \begin{array}{l}
\text { Measurement } \\
\cline { 2 - 4 } \\
\begin{array}{l}
\mathrm{ml} \text { of extract } \\
\text { used }
\end{array}
\end{array} \\
& \text { Total anthocyanin content in }=\text { Total O.D. per } 2 \mathrm{~g} \\
& \text { mg per } 2 \mathrm{~g} \text { berry } \quad 98.2
\end{aligned}
$$

\section{Determination of Lipids content}

The total lipid content of different parts of mulberry samples viz. roots, leaves and fruits were estimated by Folch et al. method [13]. About $0.2 \mathrm{gm}$ of each different mulberry samples was homogenized with $2 \mathrm{ml}$ of chloroform and methanol mixture $(2: 1 \mathrm{v} / \mathrm{v})$. The samples were taken for centrifugation for 15 minutes at 10,000 rpm. An equal amount or volume of $0.6 \%$ saline solution was added to supernatant. Weight was taken at this stage. After mixing thoroughly, the samples were transferred to separating funnel and left in dark for overnight. Later, the lower organic phase was separated and evaporated at $60^{\circ} \mathrm{C}$ in an oven. The residues of different samples was weighed for total lipids content and expressed in mg/gm sample.

\section{Statistical Analysis}

The data were subjected to standard method of analysis of variance (ANOVA) single factor, and the significance of difference between the varieties was tested using ' $f$ " criteria at $5 \%$ and $1 \%$ probability levels .Values expressed are means of three replicates. Coefficients of variation (\%) of each variety and each character were also computed.

\section{Results and Discussion}

The mean values quantitative determinations of various biochemical constituents of different varieties in leaves, fruits and roots of mulberry plant are shown in Table 1-6.

\section{Biochemical constituents of leaves}

From results of Table 1, high protein content was present in S-36 $(0.317 \mathrm{mg} / \mathrm{gm})$ and a least value was observed in AR-12 variety $(0.131 \mathrm{mg} / \mathrm{gm})$. BR-2 variety $(0.308$ 
$\mathrm{mg} / \mathrm{gm})$ holds next position in terms protein content followed by S-54 (0.215 mg/gm), S-146 (0.189 mg/gm), S-13 (0.183 mg/gm), S-1 (0.168 mg/gm) and AR-12 $(0.131 \mathrm{mg} / \mathrm{gm})$ respectively. It was also found that S-13 and S-146 are on par with each other. The differences between the mulberry varieties in terms of protein content in leaves are highly significant $(P>0.01)$. In a reporting of Food and Agricultural Organization, the total protein content when compared with other vegetables leaves, mulberry leaves showed higher protein content [12]. Adeduntan and Oyerinde [1] reported highest protein content in S-36 followed by S-54 and Kanva-2 which is accordance to present study. The high protein values observed is in agreement with Kasiviswanathan et al. [23] and it is an indication that both Mulberry can be of food value in man, silkworm and animal. Thirumalaisamy et al. [43] screened total protein content of six varieties of mulberry leaves viz S-13, S-30, S-36, Mysore Local, V-1 and RFS-135, of which V-1 recorded maximum total protein content $(26.72 \%)$ whereas in the current study S-36 variety recorded highest protein content $(0.315 \mathrm{mg} / \mathrm{gm})$. The current results are not in accordance with the findings of Thirumalaisamy et al. [43].

High carbohydrate content was observed in AR-12 variety $(0.624 \mathrm{mg} / \mathrm{gm})$ followed by $\mathrm{S}-13$ variety $(0.505$ $\mathrm{mg} / \mathrm{gm}), \mathrm{S}-1$ (0.466 mg/gm), S-54 (0.295 mg/gm), S-36 (0.247 mg/gm), BR-2 (0.239 mg/gm) and S-146 (0.180 $\mathrm{mg} / \mathrm{gm}$ ) respectively (Table 1). S-36, S-54 and BR-2 are on par with each other. AR-12 mulberry variety has recorded the highest amount of carbohydrate content and least in S-146 mulberry variety. The differences between the mulberry varieties in terms of total carbohydrates content in leaves are highly significant $(P>0.01)$. Adeduntan and Oyerinde [1] reported highest carbohydrate content in K-2 which is not in the close agreement with current study. The sensory assessment indicated that black mulberry has fruity, sweet, sour, musky and woody flavour. Koyuncu et al. [25] surveyed native black mulberry genotypes for fruit and characters. Table 2 indicated that, the total carotenoids content in different mulberry varieties and found highest in S-54 variety $(0.195 \mathrm{mg} / \mathrm{gm})$ followed by S-36 $(0.051 \mathrm{mg} / \mathrm{gm})$, BR-2 (0.037 mg/gm),S-1 (0.022 mg/gm), S-13 (0.022 $\mathrm{mg} / \mathrm{gm}), A R-12$ (0.020 mg/gm) and S-146 (0.019 mg/gm). S-13, S-146, S-1, and AR-12 are all on par with each other. A similar trend was found between protein and total carotenoids content. The differences between the mulberry varieties in terms of total carotenoids content in leaves are highly significant $(P>0.01)$.

The total lipids content was found maximum in S-13 variety i.e. $0.923 \mathrm{mg} / \mathrm{gm}$ sample while least value was recorded in AR-12 variety i.e. $0.180 \mathrm{mg} / \mathrm{gm}$ (Table 2). After S-13, S-54 variety has attained next position in lipid content i.e. $0.497 \mathrm{mg} / \mathrm{gm}$ followed by BR-2 (0.383 $\mathrm{mg} / \mathrm{gm}), \mathrm{S}-1$ (0.293mg/gm), S-146 (0.247mg/gm), S-36 $(0.223 \mathrm{mg} / \mathrm{gm})$. The differences between the mulberry varieties in terms of total lipids content in leaves are highly significant $(P>0.01)$. Adeduntan and Oyerinde [1] reported highest lipid content in S-36 variety which is not supporting to present analysis.

Krishnaswami et al . [26] observed that mulberry leaves containing water, protein total sugars, soluble carbohydrates, less minerals and crude fiber is best relished by different animals. According to Bose et al [7], S-34 cultivar was having maximum value of moisture, total minerals, non-reducing sugars, total sugars, total carbohydrate, and total free amino acids and concluded that S-34 being the most nutritive variety in rainfed conditions while the current analysis showed that AR-12 mulberry genotype being most nutritive ones under irrigated conditions in the reference region.

\section{Biochemical constituents of fruits}

Protein content, carbohydrate, total carotenoids, total anthocyanins and total lipids of fruits of different mulberry are given in Table 3 and 4 . Among the different mulberry fruits varieties, S-36 varieties $(0.281 \mathrm{mg} / \mathrm{gm})$ contain highest concentration of protein followed by S-13 $(0.246$ $\mathrm{mg} / \mathrm{gm})$, AR-12 (0.237 mg/gm), BR-2 (0.227 mg/gm), S54 (0.185 mg/gm), S-146 (0.166 mg/gm) and S-1 (0.128 $\mathrm{mg} / \mathrm{gm}$ ) (Table 3). However, this value was found to be lower in S-1 variety $(0.1029 \mathrm{mg} / \mathrm{gm})$. A different trend was found between the protein content of leaves and fruits. S-36 variety is the only common one found in both leaves and fruits. AR-12 and BR-2 are on par with each other. The differences between the mulberry varieties in terms of total lipids content in leaves are highly significant $(P>0.01)$.

On the other hand, the carbohydrate contents in different mulberry fruits showed an incredible variation among different mulberry genotypes (Table 3). The carbohydrate levels in different mulberry fruits were found to be highest in S-36 $(0.6548 \mathrm{mg} / \mathrm{gm})$ and least found in BR-2 (0.3733 mg/gm). S-54 variety (0.582 $\mathrm{mg} / \mathrm{gm}$ ) recorded second highest carbohydrate content variety followed by AR-12 (0.521 mg/gm), S-1 (0.478 $\mathrm{mg} / \mathrm{gm}), \mathrm{S}-146$ (0.443 mg/gm), S-13 (0.415 mg/gm) and BR-2 $(0.373 \mathrm{mg} / \mathrm{gm})$. The differences between the mulberry varieties in terms of total lipids content in leaves are highly significant $(P>0.01)$.

In a preceding reporting, the carbohydrate content in mulberry fruit of Turkey region is $20.4 \%$ [11]. Difference in sugars content amongst cultivars has also been reported by other scientists [2, 10, 16, 19]. However, values noted in present study were higher than those of Hussain [19] and Elmac and Altuq [10] and lower than those of Gosh et al. [16]. Iqbal Khan and Munir [20] reported total sugars content in mulberry fruits grown in Pakistan region ranged between 21.163 to $34.777 \%$ while in current study it range about $0.373 \mathrm{mg} / \mathrm{gm}-0.655$ $\mathrm{mg} / \mathrm{gm}$.

The total carotenoids content of the evaluated mulberry fruits varieties varied between $0.0067 \mathrm{mg} / \mathrm{gm}$ to 0.0098 $\mathrm{mg} / \mathrm{gm}$ (Table 4) .It was found that variability of total carotenoids content among different mulberry fruit samples was very less. AR-12 variety contains highest values $(0.0095 \mathrm{mg} / \mathrm{gm})$ and lowest in S-13 (0.006 $\mathrm{mg} / \mathrm{gm})$. 
There was constricted range of total carotenoids content in different mulberry fruits cultivars. Although AR-12 stood first position in total carotenoids content, S-36 and BR-2 followed very closely (insignificant difference) i.e. $0.009 \mathrm{mg} / \mathrm{gm}$. Almost all the mulberry varieties are very close to each other in relation to total carotenoids content. The differences between the mulberry varieties in terms of total carotenoids content in fruits are highly significant $(P>0.01)$.

The total anthocyanins content of mulberry fruits samples contain an appreciable amount in S-146 and AR-12 varieties $(102.76 \mathrm{mg} / 2 \mathrm{gm}$ sample and 102.41 $\mathrm{mg} / 2 \mathrm{gm}$ sample).On the other hand, S-1 variety contains least amount of total anthocyanins content (19.94mg/2gm sample) (Table 4). BR-2 (98.653 mg/2 gm sample) mulberry variety holds the next position in terms of anthocyanins content followed by S-36 (93.387 $\mathrm{mg} / 2 \mathrm{gm}$ sample), S-54 (90.550 mg/2 gm sample), S-13 (21.887 mg/2 gm sample). S-36 and S-54 are on par with each other.

Anthocyanin content depends on climate, area of cultivation, and is particularly higher in sunny climates [31]. The differences between the mulberry varieties in terms of total anthocyanins content in fruits are highly significant $(P>0.01)$. Total anthocyanins levels was found highest in S-146 and AR-12 varieties and are widely found in all other varieties except S-1 and S-13 variety since its color was creamish-white. However, the estimated total anthocyanins content of different mulberry cultivars of Korea ranges from 1229 to $2057 \mu \mathrm{g}$ Ig [40] whereas in India, it ranges from $19.94 \mathrm{mg} / 2 \mathrm{~g}$ sample to $102.76 \mathrm{mg} / 2 \mathrm{gm}$ sample. On the other hand, Xiuming Liu and his co-workers [29] found the total anthocyanins content of different mulberry fruits cultivars ranges from $147.68 \mathrm{mg} / \mathrm{l}$ to $2725 \mathrm{mg} / \mathrm{l}$.

The total lipids content in different mulberry fruits samples was found maximum in S-13 $(1.110 \mathrm{mg} / \mathrm{gm})$ while least content recorded in S-36 mulberry variety $(0.567 \mathrm{mg} / \mathrm{gm})$.Next to $\mathrm{S}-13$ variety, AR-12 variety $(0.920 \mathrm{mg} / \mathrm{gm})$ recorded, followed by S-1 $(0.863 \mathrm{mg} / \mathrm{gm})$, BR-2 (0.783 mg/gm), S-146 (0.670 mg/gm), S-54 (0.627 $\mathrm{mg} / \mathrm{gm}$ ) lipid content (Table no. 4). Moreover, cultivars, soil and climatic conditions do have influence on the composition of fruits [20]. The differences between the mulberry varieties in terms of total lipids content in fruits are significant $(P>0.05)$.

\section{Biochemical constituents of roots}

The biochemical constituents like protein, carbohydrate, total carotenoids and total lipids content of roots of different mulberry genotypes were shown in Table no.5 and 6 . There were scanty reports available regarding biochemical composition of roots in different mulberry varieties. The protein content in different mulberry roots samples was peak recorded in AR-12 mulberry variety (0.374 $\mathrm{mg} / \mathrm{gm})$ while BR-2 variety $(0.197 \mathrm{mg} / \mathrm{gm})$ recorded dip value. Next to AR-12 mulberry variety, S146 variety $(0.266 \mathrm{mg} / \mathrm{gm})$ stood next position in respect to protein content followed by S-13 $(0.254 \mathrm{mg} / \mathrm{gm}), \mathrm{S}-1$ (0.245 mg/gm), S-36 (0.241 mg/gm) and S-54 (0.224 $\mathrm{mg} / \mathrm{gm}$ ) (Table 5). This trend was quite different from that of protein content in leaves. The differences between the mulberry varieties in terms of protein content in roots are highly significant $(P>0.01)$.

The carbohydrate content in different mulberry roots samples, S-13 variety $(0.560 \mathrm{mg} / \mathrm{gm})$ recorded maximum value while it was on fewer pars in BR-2 mulberry variety (0.2146 mg/gm) (Table no-5). AR-12 mulberry variety (0.369 $\mathrm{mg} / \mathrm{gm})$ recorded carbohydrate content next to S13 variety followed by S-146 (0.317 mg/gm),S-1 (0.278 $\mathrm{mg} / \mathrm{gm}), \mathrm{S}-36(0.265 \mathrm{mg} / \mathrm{gm}), \mathrm{S}-54(0.263 \mathrm{mg} / \mathrm{gm})$ and BR-2 (0.214 $\mathrm{mg} / \mathrm{gm})$. The differences between the mulberry varieties in terms of carbohydrate content in roots are highly significant $(P>0.01)$.

The total carotenoids content was not found variably in different mulberry roots samples and its values indicated (Table no-6) that S-1 (0.0077 mg/gm) and S-36 variety ( $0.0074 \mathrm{mg} / \mathrm{gm})$ recorded maximum and near values while BR-2 mulberry variety $(0.0045 \mathrm{mg} / \mathrm{gm})$ recorded least total carotenoids when compared to other mulberry varieties. S-146 mulberry variety $(0.0067 \mathrm{mg} / \mathrm{gm})$ recorded next position followed byAR-12 (0.0062 $\mathrm{mg} / \mathrm{gm})$. S-54 and S-13 mulberry varieties recorded same total carotenoids content i.e. $0.0056 \mathrm{mg} / \mathrm{gm}$. Again the differences between the mulberry varieties in terms of total carotenoids content in roots are highly significant ( $P>0.01)$.

The total lipids content among different roots samples, S13 variety $(0.883 \mathrm{mg} / \mathrm{gm})$ recorded highest value while least found in S-146 variety $(0.190 \mathrm{mg} / \mathrm{gm})$.AR-12 variety $(0.593 \mathrm{mg} / \mathrm{gm})$ holds next position in lipid content followed by BR-2 (0.483 mg/gm), S-54 (0.404mg/gm), S1 (0.360 mg/gm), S-36 (0.210 mg/gm) and S-146 (0.190 $\mathrm{mg} / \mathrm{gm}$ ) (Table no-6). The differences between the mulberry varieties in terms of total lipids content in roots are highly significant $(P>0.01)$.

\section{Conclusion}

In India, AR-12 mulberry variety at present can be cultivated not only for rearing of silkworms but also it will open the way to corporate sericulture system through which these varieties can be explored by herbal druggists as health supplements in pharmaceutical industry thereby making moriculture as profitable enterprise.

\section{Acknowledgment}

The authors are obliged to Hon'ble Vice- Chancellor Prof. B. Hanumaiah, Babasaheb Bhimrao Ambedkar University, for his guidance and support.

\section{References}

[1] Adeduntan S. A. and Oyerinde A. S. (2010) African Journal of Biochemistry Research, 4(7), 175-178.

[2] Ahmad I. and Sadozai M. A. (2003) NTFP Directorate, Khyber Pakhtunkhwa Forest Deptt. Peshawar,50-54. 
[3] Anonymous (1975) Japan Overseas Cooperation, Tokyo, Japan,154--166.

[4] Armand D. et Meuret M. (1995) Institute National de la Recherche Agronomique, Avignon, France.

[5] Asano N, Tomioka E, Kizu H, Matsu K (1994), Carbohydrate Res., 259 (2):243-255.

[6] Bonciarelli F. Santilocchi R. (1980) Rivista di Agronomía (Italia),14,21-29.

[7] Bose P.C., Majumder S.K., Bose G. and Dutta R.K. (1994) J. Seric., 2(1\&2),51-54.

[8] Chen F.J., Nakashima N., Kimura I., Kimura M. (1995) Yakugaku Zasshi. 115,476-482.

[9] Dubois M.K., Giller K.A., Hamilton K., Relers P.A. and Smith F.(1956) Annal. Chem.,28, 350-356.

[10] Elmac Y. and Altuq I. (2002) J. Sci. Food and Agri. 82(6),632-635.

[11] Ercisli S. and Orhan E. (2007) Food Chemistry, 103(4), 1380-1384.

[12] FAO (1990) Food and Agriculture Organisation Italy, Rome.

[13] Folch J., Lees M. and Stanley G.H.S. (1957) J. Biol. Chem., 226, 497-509.

[14] Fukai T, You -Hu P, Nomura T, Xu CQ, Wu LJ, Chen YJ (1998), Phytochemistry 47(2):273.

[15] Fukai T., Satoh K., Nomura T., Sakagami H. (2003) Fitoterapia, 74,720-724.

[16] Ghosh M.K., Das B.K., Misra A.K., Das C., Mukherjee P.K. and Urs S.R. (2006) Indian J. Pl. Physiol. 11(3),246-252.

[17] Giusti M.M., Wrolstad R.E. (2003) Biochem. Eng. J.,14(3), 217-225.

[18] Hikino H., Mizuno T., Oshima Y., Konno C. (1985) Planta Medica, 159-160.

[19] Hussain T. (1985) Govt. of Pakistan, Ministry of Planning and Development, Islamabad, 67.

[20] Iqbal Muhammad, Mir Khan and Munir Muhammad (2010) Pakistan J. Agric. Res., 48(2), 209-217.

[21] Ito T. (1972) Israel J. Entomology,7, 1-6.

[22] Jin W.Y., Na, M.K., An, R.B., Lee, H.Y., Bae, K.H., Kang, S.S. (2002) Natural Product Sciences , 8,129-132.

[23] Kasiviswanathan K., Parankumar T., Chowdhary P.C., Somashakara K.S. (1988) Lead paper 2. Central silk board Bangalore, Indian,11.

[24] Kim E.S., Park S.J., Lee E.J., Kim B.K., Huh H., Lee B.J.(1999) Archives of Pharmacal Research, 22,9-12.

[25] Koyuncu F., Koyuncu M. A., Yidrm F. and Vural E. (2004) European J. Hort. Sci., 69(3), 125-131.

[26] Krishnaswami , S., Noamani, K. R. and Ahsan, M. (1970a), Indian J. Sericulture; 9(1), 1-10.
[27] Krishnaswami (1978) Bull No-2 CSRTI, Mysore, India, 4-5.

[28] Kumaresan P., Tikader A., Kamble C.K.(2008) Indian silk, 46(11),10-11.

[29] Liu Xiuming, Xiao Gengsheng, Chen Weidong, $\mathrm{Xu}$ Yujuan and Wu Jijun (2004) Journal of Biomedicine and Biotechnology, 5, 326-331.

[30] Lowry O.H., Rosenbrough N.J., Farr A.L. and Randall R.J. (1951) J. Bilo. Chem., 193, 265275.

[31] Matus J.T., Loyola R, Vega A. (2009), Journal of Experimental Botany,60 (3), 853-867.

[32] Masilamani S., Qadri S.M.H., Dandin S.B.(2008) Indian silk, 46(11), 12-13.

[33] Maymone B., Tiberio M.E., Triulzi G.A. (1959) Annali dell'Istituto Sperimentale Zootecnico di Roma, Volume VI, Roma.

[34] Mazza G., Miniati E. (1993) Boca Raton, Florida, CRCS press.

[35] Nomura T., Fukai T., Hano Y. (2003), In: Attaur-Rahman (Ed.), Studies in Natural Product Chemistry, vol. 28: Bioactive Natural Products (Part I).Elsevier, Amsterdam, 199-256.

[36] Nomura T. (1988), In: Herz, W., Grisebach, H., Kirby, G.W., Tamm, Ch.(Eds.), Progress in the Chemistry of Organic Natural Products, 53. Springer, Vienna, 87-201.

[37] Pazmino- Duran A.E., Giusti M.M., Wrolstad R.E., Gloria M.B.A.(2001) Food Chem., 75(2), 211-216.

[38] Ranganna S. (1998) Oxford Publishing Company, New Delhi, India.

[39] Sharma R., Sharma A., Shono T., Takasugi M., Shirata A., Fujimura T., Machii H. (2001) Bioscience, Biotechnology, and Biochemistry, 65,1402-1405.

[40] Song Hwan Bae and Hyung- Joo Suh, (2007) Food Science and Technology,40(6), 955-962.

[41] Suh H.J., Noh D.O., Kang C.S., Kim J.M. and Lee S.W. (2003) Nahrung/food, 47(2), 132135.

[42] Talamucci P. and Pardini A. (1993) REUR Technical Series 28, FAO, Rome,206-209.

[43] Thirumalaisamy R., Gowrishankar J., Suganthapriya S., Prakash B., Ashok Kumar L. and Arunachalam G. (2009), J. Biomed. Sci. and Res., 1 (1), 11-18.

[44] Vezzani V. (1938) Ministerio dell'Agricoltura e delle Foreste, Roma,7-17.

[45] Yagi M., Kouno T., Aoyagi Y., Murai H. (1976) Nippon Nogei Kagaku Kaishi , 50, 571-572.

[46] Zepeda J. (1991) Medio Ambiente (Perú) 47, 28-29. 
Table 1- Biochemical constituents (Protein and Carbohydrates) in leaves of different mulberry varieties

\begin{tabular}{|c|c|c|c|c|c|c|c|}
\hline \multirow[t]{2}{*}{ SI. No. } & \multirow{2}{*}{$\begin{array}{l}\text { Mulberry } \\
\text { varieties }\end{array}$} & \multicolumn{3}{|c|}{ Protein Content (in mg/gm) } & \multicolumn{3}{|c|}{ Carbohydrate Content (in mg/gm) } \\
\hline & & Mean & S.D. & CV\% & Mean & S.D. & CV\% \\
\hline 1. & AR-12 & 0.131 & 0.002 & 1.770 & 0.624 & 0.058 & 9.309 \\
\hline 2. & S-54 & 0.215 & 0.003 & 1.480 & 0.295 & 0.051 & 17.138 \\
\hline 3. & S-13 & 0.183 & 0.002 & 1.023 & 0.505 & 0.014 & 2.712 \\
\hline 4. & S-36 & 0.317 & 0.004 & 1.113 & 0.247 & 0.006 & 2.267 \\
\hline 5. & $\mathrm{Br}-2$ & 0.308 & 0.008 & 2.528 & 0.239 & 0.008 & 3.160 \\
\hline 6. & S-146 & 0.189 & 0.003 & 1.480 & 0.180 & 0.006 & 3.434 \\
\hline 7. & S-1 & 0.168 & 0.002 & 1.196 & 0.466 & 0.056 & 12.069 \\
\hline \multicolumn{2}{|c|}{ Inference } & \multicolumn{3}{|c|}{$\mathrm{HS}$} & \multicolumn{3}{|c|}{ HS } \\
\hline \multicolumn{2}{|c|}{ CD 5\% } & \multicolumn{3}{|c|}{0.007} & \multicolumn{3}{|c|}{0.064} \\
\hline \multicolumn{2}{|c|}{ CD 1\% } & \multicolumn{3}{|c|}{0.009} & \multicolumn{3}{|c|}{0.089} \\
\hline
\end{tabular}

Note: SD-Standard deviation of mean CV\% - Coefficient of Variation in \% CD at 1\% -Critical difference at 1\% level risk CD at 5\% -Critical difference at5\% level risk HS- Highly Significant

Table 2- Biochemical constituents (Total Carotenoids and Lipids content) in leaves of different mulberry varieties

\begin{tabular}{|c|c|c|c|c|c|c|c|}
\hline \multirow[t]{2}{*}{ Sl. No. } & \multirow{2}{*}{$\begin{array}{l}\text { Mulberry } \\
\text { varieties }\end{array}$} & \multicolumn{3}{|c|}{ Total Carotenoids (in mg/gm) } & \multicolumn{3}{|c|}{ Lipids content (in mg/gm) } \\
\hline & & Mean & S.D. & CV\% & Mean & S.D. & CV\% \\
\hline 1. & AR-12 & 0.020 & 0.003 & 13.765 & 0.180 & 0.036 & 20.031 \\
\hline 2. & S-54 & 0.195 & 0.004 & 2.037 & 0.497 & 0.116 & 23.336 \\
\hline 3. & S-13 & 0.022 & 0.002 & 8.457 & 0.923 & 0.076 & 8.272 \\
\hline 4. & S-36 & 0.051 & 0.002 & 3.901 & 0.223 & 0.061 & 27.359 \\
\hline 5. & $\mathrm{Br}-2$ & 0.037 & 0.003 & 8.578 & 0.383 & 0.100 & 26.130 \\
\hline 6. & S-146 & 0.019 & 0.003 & 15.032 & 0.247 & 0.060 & 24.437 \\
\hline 7. & S-1 & 0.022 & 0.002 & 11.202 & 0.293 & 0.091 & 30.933 \\
\hline \multicolumn{2}{|c|}{ Inference } & \multicolumn{3}{|c|}{$\mathrm{HS}$} & \multicolumn{3}{|c|}{$\mathrm{HS}$} \\
\hline \multicolumn{2}{|c|}{ CD 5\% } & \multicolumn{3}{|c|}{0.005} & \multicolumn{3}{|c|}{0.142} \\
\hline \multicolumn{2}{|c|}{ CD 1\% } & \multicolumn{3}{|c|}{0.007} & \multicolumn{3}{|c|}{0.197} \\
\hline
\end{tabular}

Note: SD-Standard deviation of mean CV\% - Coefficient of Variation in \% CD at 1\% -Critical difference at 1\% level risk CD at 5\% -Critical difference at5\% level risk HS- Highly Significant

Table 3- Biochemical constituents (Protein and Carbohydrates) in fruits of different mulberry varieties

\begin{tabular}{|c|c|c|c|c|c|c|c|}
\hline \multirow[t]{2}{*}{ Sl. No. } & \multirow{2}{*}{$\begin{array}{l}\text { Mulberry } \\
\text { varieties }\end{array}$} & \multicolumn{3}{|c|}{ Protein Content (in mg/gm) } & \multicolumn{3}{|c|}{ Carbohydrate Content (in mg/gm) } \\
\hline & & Mean & S.D. & CV\% & Mean & S.D. & CV\% \\
\hline 1. & AR-12 & 0.237 & 0.007 & 2.922 & 0.521 & 0.006 & 1.113 \\
\hline 2. & S-54 & 0.185 & 0.004 & 2.079 & 0.582 & 0.008 & 1.295 \\
\hline 3. & $\mathrm{~S}-13$ & 0.246 & 0.010 & 4.015 & 0.415 & 0.004 & 0.975 \\
\hline 4. & S-36 & 0.281 & 0.007 & 2.598 & 0.655 & 0.006 & 0.847 \\
\hline 5. & $\mathrm{Br}-2$ & 0.227 & 0.006 & 2.651 & 0.373 & 0.002 & 0.661 \\
\hline 6. & S-146 & 0.166 & 0.003 & 2.019 & 0.443 & 0.005 & 1.028 \\
\hline 7. & S-1 & 0.128 & 0.002 & 1.817 & 0.478 & 0.004 & 0.864 \\
\hline \multicolumn{2}{|c|}{ Inference } & \multicolumn{3}{|c|}{$\mathrm{HS}$} & \multicolumn{3}{|c|}{$\mathrm{HS}$} \\
\hline \multicolumn{2}{|c|}{ CD 5\% } & \multicolumn{3}{|c|}{0.011} & \multicolumn{3}{|c|}{0.009} \\
\hline \multicolumn{2}{|c|}{ CD 1\% } & \multicolumn{3}{|c|}{0.015} & \multicolumn{3}{|c|}{0.012} \\
\hline
\end{tabular}

Note: SD-Standard deviation of mean CV\% - Coefficient of Variation in \% CD at 1\% -Critical difference at 1\% level risk CD at 5\% -Critical difference at5\% level risk HS- Highly Significant 
Table 4- Biochemical constituents (Total Carotenoids, Lipids content and Total Anthocyanins) in fruits of different mulberry varieties

\begin{tabular}{|c|c|c|c|c|c|c|c|c|c|c|}
\hline Sl. No. & Mulberry & \multicolumn{3}{|c|}{ Total Carotenoids (in mg/gm) } & \multicolumn{3}{c|}{ Total Anthocyanins (in mg/gm) } & \multicolumn{3}{c|}{ Lipids content (in mg/gm) } \\
\cline { 3 - 12 } & & varieties & S.D. & CV\% & Mean & S.D. & CV\% & Mean & S.D. & CV\% \\
\hline 1. & AR-12 & 0.010 & 0.001 & 12.935 & 102.413 & 0.825 & 0.806 & 0.920 & 0.192 & 20.823 \\
\hline 2. & S-54 & 0.007 & 0.001 & 14.394 & 90.550 & 2.062 & 2.277 & 0.627 & 0.131 & 20.826 \\
\hline 3. & S-13 & 0.006 & 0.001 & 8.436 & 21.887 & 0.814 & 3.719 & 1.110 & 0.151 & 13.633 \\
\hline 4. & S-36 & 0.009 & 0.000 & 4.028 & 93.387 & 7.093 & 7.595 & 0.567 & 0.155 & 27.358 \\
\hline 5. & Br-2 & 0.009 & 0.001 & 8.505 & 98.653 & 0.474 & 0.481 & 0.783 & 0.160 & 20.439 \\
\hline 6. & S-146 & 0.008 & 0.001 & 15.272 & 102.763 & 1.578 & 1.536 & 0.670 & 0.184 & 27.399 \\
\hline 7. & S-1 & 0.007 & 0.001 & 12.222 & 19.943 & 0.218 & 1.094 & 0.863 & 0.120 & 13.916 \\
\hline \multicolumn{3}{|c|}{ Inference } & \multicolumn{3}{|c|}{ HS } & \multicolumn{3}{c|}{ HS } & \multicolumn{3}{c|}{ S } \\
\hline \multicolumn{3}{|c|}{ CD 5\% } & \multicolumn{3}{|c|}{0.002} & & \multicolumn{3}{c|}{0.270} \\
\hline \multicolumn{3}{|c|}{ CD 1\% } & \multicolumn{3}{|c|}{7.037} \\
\hline
\end{tabular}

Note: SD-Standard deviation of mean CV\% - Coefficient of Variation in \% CD at 1\% -Critical difference at 1\% level risk CD at 5\% -Critical difference at5\% level risk HS- Highly Significant S-Significant

Table 5- Biochemical constituents (Protein and Carbohydrates) in roots of different mulberry varieties

\begin{tabular}{|c|c|c|c|c|c|c|c|}
\hline \multirow[t]{2}{*}{ Sl. No. } & \multirow{2}{*}{$\begin{array}{l}\text { Mulberry } \\
\text { varieties }\end{array}$} & \multicolumn{3}{|c|}{ Protein Content (in mg/gm) } & \multicolumn{3}{|c|}{ Carbohydrate Content (in mg/gm) } \\
\hline & & Mean & S.D. & CV\% & Mean & S.D. & CV\% \\
\hline 1. & AR-12 & 0.374 & 0.005 & 1.244 & 0.369 & 0.009 & 2.558 \\
\hline 2. & S-54 & 0.225 & 0.005 & 2.037 & 0.263 & 0.007 & 2.745 \\
\hline 3. & S-13 & 0.254 & 0.004 & 1.698 & 0.560 & 0.008 & 1.365 \\
\hline 4. & S-36 & 0.241 & 0.003 & 1.254 & 0.265 & 0.003 & 1.148 \\
\hline 5. & $\mathrm{Br}-2$ & 0.198 & 0.004 & 1.828 & 0.215 & 0.004 & 1.819 \\
\hline 6. & S-146 & 0.266 & 0.005 & 1.995 & 0.317 & 0.003 & 1.097 \\
\hline 7. & S-1 & 0.245 & 0.006 & 2.294 & 0.278 & 0.007 & 2.373 \\
\hline \multicolumn{2}{|c|}{ Inference } & \multicolumn{3}{|c|}{$\mathrm{HS}$} & \multicolumn{3}{|c|}{ HS } \\
\hline \multicolumn{2}{|c|}{ CD 5\% } & \multicolumn{3}{|c|}{0.008} & \multicolumn{3}{|c|}{0.011} \\
\hline \multicolumn{2}{|c|}{ CD 1\% } & \multicolumn{3}{|c|}{0.011} & \multicolumn{3}{|c|}{0.015} \\
\hline
\end{tabular}

Note: SD-Standard deviation of mean CV\% - Coefficient of Variation in \% CD at 1\% -Critical difference at 1\% level risk CD at 5\% -Critical difference at5\% level risk HS- Highly Significant

Table 6- Biochemical constituents (Total Carotenoids and Lipids content) in roots of different mulberry varieties

\begin{tabular}{|c|c|c|c|c|c|c|c|}
\hline \multirow[t]{2}{*}{ SI. No. } & \multirow{2}{*}{$\begin{array}{l}\text { Mulberry } \\
\text { varieties }\end{array}$} & \multicolumn{3}{|c|}{ Total Carotenoids (in mg/gm) } & \multicolumn{3}{|c|}{ Lipids content (in mg/gm) } \\
\hline & & Mean & S.D. & CV\% & Mean & S.D. & CV\% \\
\hline 1. & AR-12 & 0.0062 & 0.0006 & 8.9803 & 0.593 & 0.061 & 10.298 \\
\hline 2. & S-54 & 0.0056 & 0.0005 & 8.1004 & 0.404 & 0.020 & 5.046 \\
\hline 3. & S-13 & 0.0056 & 0.0006 & 10.0939 & 0.883 & 0.183 & 20.762 \\
\hline 4. & S-36 & 0.0074 & 0.0008 & 10.7260 & 0.210 & 0.020 & 9.524 \\
\hline 5. & $\mathrm{Br}-2$ & 0.0045 & 0.0003 & 5.5513 & 0.483 & 0.172 & 35.616 \\
\hline 6. & S-146 & 0.0067 & 0.0005 & 7.4751 & 0.190 & 0.075 & 39.736 \\
\hline 7. & S-1 & 0.0077 & 0.0006 & 7.9697 & 0.360 & 0.062 & 17.347 \\
\hline \multicolumn{2}{|c|}{ Inference } & \multicolumn{3}{|c|}{$\mathrm{HS}$} & \multicolumn{3}{|c|}{$\mathrm{HS}$} \\
\hline \multicolumn{2}{|c|}{ CD 5\% } & \multicolumn{3}{|c|}{0.0010} & \multicolumn{3}{|c|}{0.184} \\
\hline \multicolumn{2}{|c|}{ CD 1\% } & \multicolumn{3}{|c|}{0.0013} & \multicolumn{3}{|c|}{0.256} \\
\hline
\end{tabular}

Note: SD-Standard deviation of mean $\quad$ CV\% - Coefficient of Variation in \% CD at 1\% -Critical difference at 1\% level risk $C D$ at $5 \%$-Critical difference at5\% level risk

HS- Highly Significant 